\title{
Quebec stands firm on asbestos exports despite growing
}

\section{controversy}

Published at www.cmaj.ca on Feb. 17

$\mathrm{P}$ remier of Quebec Jean Charest is refusing to stop exporting chrysotile asbestos, despite a growing international outcry accusing Canada of hypocrisy in promoting the sale of a known carcinogen.

On a trade mission in February to India - the largest buyer of asbestos from Quebec - protests greeted Charest at two of his stops, including a summit on sustainable development in Delhi. Members of the Building and Wood Workers International Union confronted Charest, accusing Quebec and Canada of exporting a product that is neither green nor sustainable.

Before he left Quebec City, Charest also received a letter signed by 100 physicians and scientists from 28 countries, urging him to support a ban on asbestos, which is produced in Thetford Mines, Quebec.

"We appeal to you to respect the overwhelmingly consistent body of scientific evidence and the considered judgment of the World Health Organization (WHO) that all forms of asbestos have been shown to be deadly and that safe use of any form of asbestos has proven impossible anywhere in the world," the letter began. "Under Canadian law, chrysotile asbestos is classified as a hazardous substance, but the Quebec government has successfully lobbied to prevent it being recognized as such under international environmental law, thus creating a double standard of protection as if some lives were less deserving of protection than others."

The letter was cosigned by epidemiologist Devra Davis, founder of Environmental Health Trust, and Sue Janse van Rensburg, chief executive officer of the Cancer Association of South Africa, on behalf of the 98 others who lent their names to the campaign. (In 2008, South Africa banned the use, manufacturing,

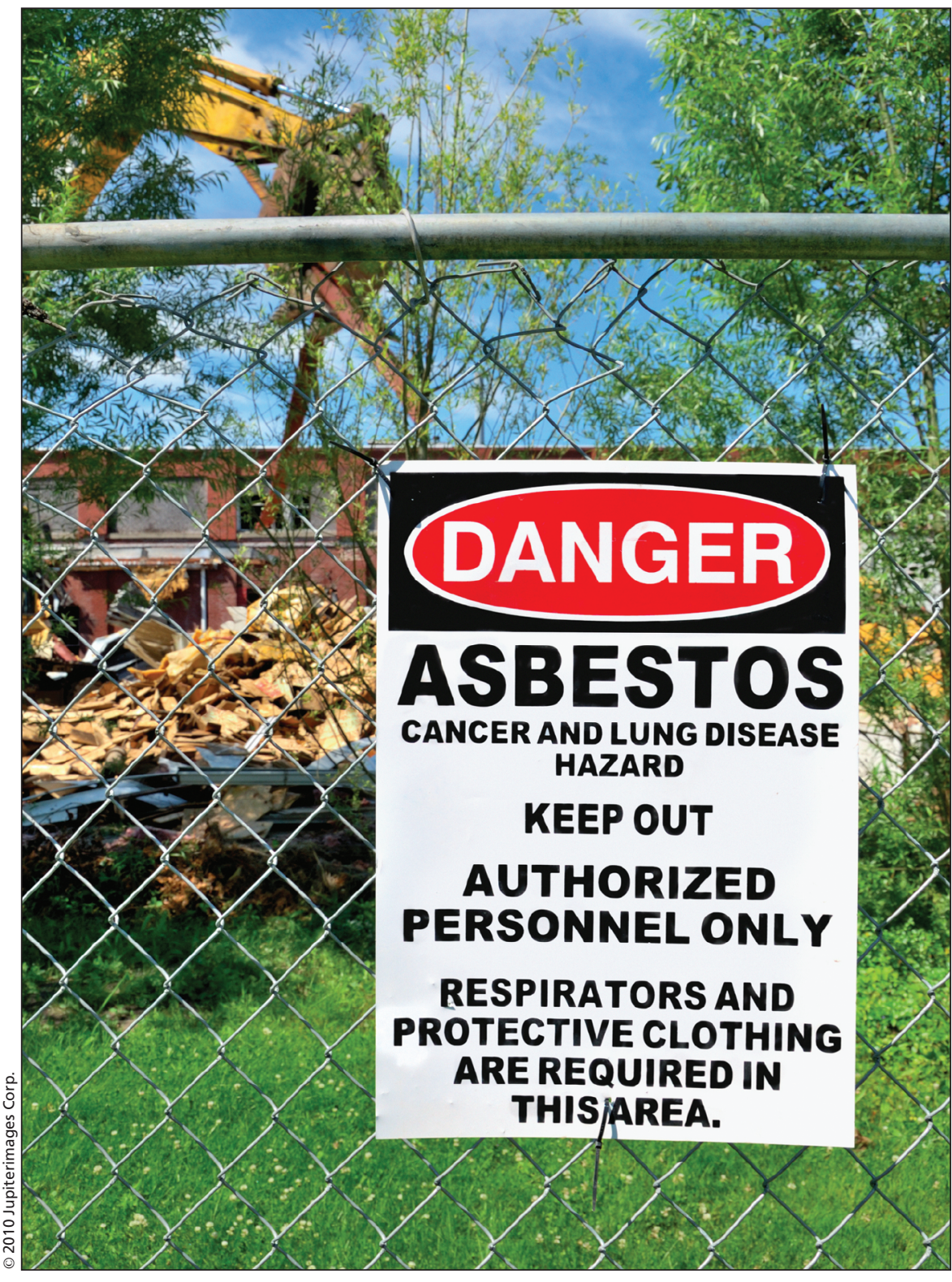

The safe use of any form of asbestos is "impossible anywhere in the world," states a letter to Quebec Premier Jean Charest signed by physicians and doctors from 28 countries.

import and export of asbestos except for specific exemptions.)

But Charest told reporters in a postsummit press conference that chrysotile asbestos can be used safely. "There is a limit" to what Quebec can do, Charest said, adding that it is up to the Indian government to put standards in place to ensure the safe handling of chrysotile asbestos.

The premier's stance is "a crazy position in terms of science" and is based on politics and the need to protect about 700 jobs in Thetford Mines, 
charges Dr. Francois Turcotte, a professor emeritus of public health at Laval University in Québec City, Quebec, and one of the signatories on the letter.

Charest's stance hurts Canada's international reputation, Turcotte adds, noting that at the same time that Quebec is exporting asbestos, it is removing it from schools and public buildings.

"It gives us a horrible standing on the international scene, where we seem to be insisting on having the right to continue polluting the planet, just to save a few hundred jobs," Turcotte says. "As Canadians, we are behaving like a bunch of insensitive gangsters or poison-peddlers on the international scene."

The Environmental Health Trust and other groups protesting the sale of asbestos have also urged Quebec and Canada to stop funding the Chrysotile Institute, a lobby group devoted to promoting the sale of chrysotile asbestos.

"It has a huge budget," says Turcotte. "This money would have been a hundred times more useful if it had been used to support the economic adjustment of workers who are earning their living mining the stuff."

Davis, who heads the Environmental Health Trust, says Canada's position on asbestos is "unconscionable."

"By what right does a country like Canada, which is effectively banning its own use of asbestos ... at the same time, export it to countries like India, where already in some areas one out of five workers has asbestos-related disease?" she asks. "We are basically exporting a clear cause of deaths and disability."

The Canadian Cancer Society has also called on the federal, provincial and territorial governments to adopt a clear timetable for phasing out the use and export of asbestos. "Countries importing chrysotile asbestos from Canada should be fully informed of the human health and environmental risks associated with its use," the society says on its website. It also calls on Canada to support the addition of chrysotile asbestos to a list of hazardous chemicals that can only be imported if countries provide informed consent (CMAJ 2008. DOI:10.1503/cmaj.081806).

Researchers with the Mexican Institute of Social Security documented 119 cases of pleural mesothelioma in 472 workers in Mexico, with $80.6 \%$ of cases and $31.5 \%$ of controls having occupational exposure to asbestos (Am J Ind Med 2010. DOI:10.1002/ajim.20780). The majority of chrysotile asbestos used in Mexico comes from Canada.

The authors of the study, who predict an increase in cases of mesothelioma in Mexico due to workers' exposure, call on Mexico to ban the import of asbestos and to charge companies responsible for exposing workers for the costs of their health care. Canadian asbestos exports are "a deplorable example of the manner in which dangerous industries are being deliberately exported to Mexico and less industrialized countries." - Laura Eggertson, Ottawa, Ont.

DOI:10.1503/cmaj.109-3184 